\title{
基于薄层反应器的有机污染物光电催化氧化反应性能与机理
}

\author{
郑 青 ${ }^{1}$, 李金花 ${ }^{1}$, 陈红冲 ${ }^{1}$, 陈全鹏 ${ }^{1}$, 周保学 ${ }^{1,2,}{ }^{*}$, 尚树 ( $^{3}$, 蔡伟民 ${ }^{1}$ \\ ${ }^{1}$ 上海交通大学环境科学与工程学院, 上海 200240 \\ ${ }^{2}$ 上海交通大学薄膜与微细技术教育部重点实验室, 上海 200240 \\ 3 山东师范大学化学化工与材料科学学院, 山东济南 250014
}

\begin{abstract}
摘要: 基于薄层反应器快速耗竭氧化特点, 研究了典型环境内分泌干扰物双酚 $\mathrm{A}$ 在 $\mathrm{TiO}_{2}$ 纳米管阵列电极上的光电催化氧化反 应性能与反应机理. 结果表明, 薄层反应器中光电流、初始峰值电流、耗竭反应净电量和空白光电流等光电催化物理参数均能 反映光电催化反应速率, 并适用于催化反应的机制分析. 峰值光电流与双酚 $\mathrm{A}$ 初始浓度拟合结果表明, 双酚 $\mathrm{A}$ 在电极表面的吸 附符合朗格缪尔等温吸附方程, 且光电流与吸附浓度正相关, 而瞬态光电流时间响应曲线拟合结果发现, 双酚 A在电极表面光 电催化过程随时间呈一级指数衰减模型变化, 且该模型也适合于乙二醇、谷氨酸、酒石酸、甲醇、二乙醇胺和尿素等其他有机 物的光电催化氧化过程. 可为各种光电催化传感器实时监测有机物浓度提供理论基础, 并可用于快速比较测定多种纳米电极材 料的催化性能.
\end{abstract}

关键词: 光电催化; 二氧化钛阵列; 薄膜反应器; 有机物降解; 双酚 $\mathrm{A}$

中图分类号: 0643/X7 文献标识码: A

收稿日期: 2011-04-11. 接受日期: 2011-05-27.

*通讯联系人. 电话: (021)54747351; 电子信箱: zhoubaoxue@sjtu.edu.cn

基金来源：国家高技术研究发展计划 (863 计划, 2009AA063003); 国家重点基础研究发展计划 (973 计划, 2009CB220004); 上 海市科学技术委员会项目 (0952nm01800).

本文的英文电子版(国际版)由Elsevier出版社在 ScienceDirect 上出版(http://www.sciencedirect.com/science/journal/18722067).

\section{Characterization and Mechanism of the Photoelectrocatalytic Oxidation of Organic Pollutants in a Thin-Layer Reactor}

\author{
ZHENG Qing ${ }^{1}$, LI Jinhua ${ }^{1}$, CHEN Hongchong ${ }^{1}$, CHEN Quanpeng ${ }^{1}$, ZHOU Baoxue $^{1,2, *}$, \\ SHANG Shuchuan ${ }^{3}$, CAI Weimin ${ }^{1}$ \\ ${ }^{1}$ School of Environmental Science and Engineering, Shanghai Jiao Tong University, Shanghai 200240, China \\ ${ }^{2}$ Key Laboratory for Thin Film and Microfabrication of the Ministry of Education, Shanghai Jiao Tong University, Shanghai 200240, China \\ ${ }^{3}$ College of Chemistry, Chemical Engineering and Materials Science, Shandong Normal University, Jinan 250014, Shandong, China
}

\begin{abstract}
The characterization and mechanism of the photoelectrocatalytic oxidation of a typical endocrine disrupting chemical, bisphenol-A (BPA), on $\mathrm{TiO}_{2}$ nanotube arrays (TNAs) were investigated using a thin-layer reactor where BPA was rapidly and exhaustively oxidized. Physical parameters such as the photocurrent, the initial peak photocurrent, the exhaustive charge quantity, and the blank photocurrent were found to be related to the degradation rate and the reaction mechanism. The Langmuir equation was used to fit the relationship between the initial peak photocurrent response and the BPA concentration indicating the proportionality between the photocurrent responses and the adsorbed organic concentration. A first-order exponential decay fitting of transient photocurrent profiles indicated the validity of first-order organic degradation kinetics for the photoelectrocatalysis. These relationships were found to be valid for many other organics including urea, glycol, glumatic acid, tartaric acid, methanol, and diethanolamine. The quantitative relationship found in this study provides a theoretical foundation for the real-time determination of the degradability of toxic organics by photoelectrocatalytic sensors.
\end{abstract}

Key words: photoelectrocatalysis; titania nanotube array; thin-layer reactor; organic degradation; bisphenol A 
This work was supported by the National High Technology Research and Development Program of China (863 Program, 2009AA063003), the National Basic Research Program of China (973 Program, 2009CB220004), and the Science and Technology Commission of Shanghai Municipality (0952nm01800).

English edition available online at Elsevier ScienceDirect (http://www.sciencedirect.com/science/journal/18722067).

Photoelectrocatalysis (PEC) using wide bandgap semiconductors is a well-established method to completely degrade and mineralize various hazardous pollutants in an aqueous environment $[1,2]$. The activity of $\mathrm{TiO}_{2}$ photocatalysts and the configuration of reactors are both critical to influence the treatment kinetics of heterogeneous PEC degradation. Much effort has been devoted to improving the photocatalytic ability of $\mathrm{TiO}_{2}$ catalysts including the synthesis of new $\mathrm{TiO}_{2}$ structures. Recently, integrated photoanodes based on $\mathrm{TiO}_{2}$ nanotube arrays (TNAs) have attracted considerable attention because of their peculiar architecture and remarkable properties during water splitting [3] and for the photoelectrocatalytic degradation [4] of organic dyes, phenol, formic acid, and oxalic acid. The unidirectional electric channel for the rapid transportation of photoelectrons enables TNAs to have a higher photoelectric efficiency compared with immobilized nanoparticulate electrodes [5,6]. On the other hand, the treatment efficiency is also affected by the configuration of the reactor and many reactors have also been developed including Pyrex annular reactors [7], continuous flow electrode-packed bed reactors [8], optical fiber fixed bed reactors [9], spinning disk reactors [10], three-dimensional hollow quartz tube reactors [11], and poly-functional slurry reactors [12]. Despite extensive research on TNA structures and their related properties in various reactors [13-16], research into the photoelectrocatalytic reaction mechanism of these structures is scarce.

Previous studies into the degradation mechanism of $\mathrm{TiO}_{2}$ were mainly performed in bulk reactors where the concentration of pollutants was determined repeatedly over a certain period of time by absorption spectrophotometry [17]. This evaluation method limited in-depth investigation into the reaction mechanism. In traditional bulk reactors such as immobilized reactors the organic molecules are slowly transferred from the bulk solution to the surface of the $\mathrm{TiO}_{2}$ nanomaterials through long diffusion channel by concentration gradient resulting in a long period of time for organic mineralization [17]. When a thin-layer reactor with a small cavity volume was used the adsorption characteristics of different organics and their interactions with the catalyst can be studied more easily since the application of this technology increases the ratio of the photoanode area and the organic solution volume so that an exhaustive redox reaction can be completed quickly [18]. A thin-layer cell with a short diffusion channel can simplify the kinetic study of the degradation processes without the influence of bulk solution effects. Besides, it helps to evaluate information about the maximum catalytic ability of a heterogeneous reaction system to identify the limiting steps and to optimize the catalytic conditions for photoanodes [18]. Therefore, an investigation into the degradation characteristics of the organics in a thin-layer reactor is crucial for a kinetic and mechanistic study of TNA photoelectrocatalysis.

We have previously reported about the preparation of Ti-based and conductive glass substrate based TNAs and $\mathrm{TiO}_{2}$ nanopore arrays with different morphological characteristics and applied them as anodes in photoelectrochemical applications such as in water splitting [19-21], organic pollutant degradation [22], and chemical oxygen demand determination $[23,24]$. In this study, the photoelectric signals obtained from a closed thin-layer reactor were used to investigate the photoelectrocatalytic process, which is simple, accurate, safe, and rapid. The endocrine disrupting chemical bisphenol-A (BPA) was chosen as a model organic because of its toxicity to humans including effects such as hormonal imbalance, male infertility, prostate, and breast cancer [25]. After the determining the reaction kinetics using the initial peak photocurrent, an exhaustive charge quantity and blank photocurrent investigation was generalized to other common organics including urea, glycol, glumatic acid, tartaric acid, methanol, and diethanolamine.

\section{Experimental}

\subsection{Preparation of TNAs}

Highly-ordered TNA samples were prepared by electrochemical anodization as our previous protocol [23]. In brief, titanium foil $(99.9 \%, 0.25 \mathrm{~mm}$ thickness, Kurumi Works, Japan) was ultrasonically degreased in Micro-90 solution, acetone, and methanol followed by rinsing with deionised water and drying in air. The electrochemical setup consisted of a two-electrode configuration with $\mathrm{Ti}$ as the anode and platinum foil as the cathode. The Ti foil was anodized at 20 $\mathrm{V}$ for $1 \mathrm{~h}$ in a $0.5 \% \mathrm{HF}$ solution. A DC power supply (Tradex, MPS 305, China) was used as the voltage source to drive the anodization and a multimeter was used to record the resulting current. After anodization, the samples were annealed in a muffle furnace at $450{ }^{\circ} \mathrm{C}$ for $3 \mathrm{~h}$ to crystallize in an air ambience at a heating and cooling rate of $1{ }^{\circ} \mathrm{C} / \mathrm{min}$.

\subsection{Assembly of the thin-layer reactor}


The photoelectrochemical oxidation was carried out in a thin-layer reactor (Fig. 1), which consists of six main components: the cell body, a TNA photoanode, a Pt cathode, a saturated $\mathrm{AgCl} / \mathrm{Ag}$ reference electrode, an inlet, and an outlet. The cell body was assembled by compressing two Teflon boards and adding a central spacer (100 $\mu \mathrm{m}$ thicknesses) and these were held together with screws, bolts, and nuts. A quartz window $\left(0.785 \mathrm{~cm}^{2}\right)$ was embedded into the front Teflon board and it was used to admit illumination. All the interstices were sealed with silicone gel to keep the reactor airtight [5].

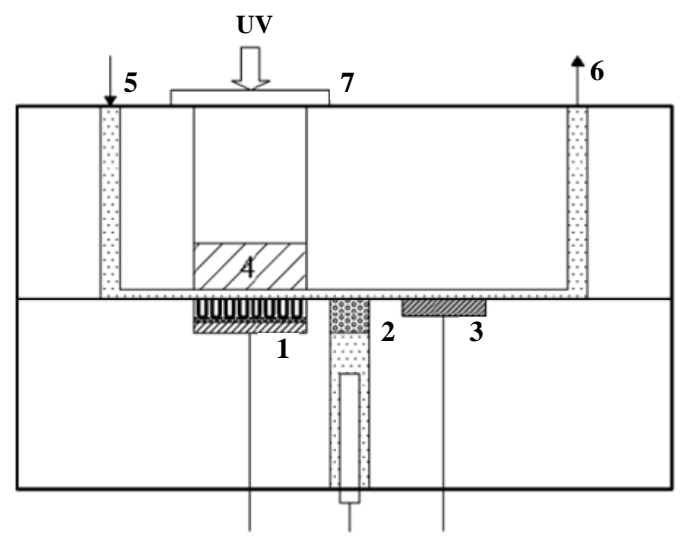

Fig. 1. Schematic diagram of the thin-layer reactor [5]. (1) TNA electrode; (2) Saturated $\mathrm{AgCl} / \mathrm{Ag}$ reference electrode; (3) Pt counter electrode; (4) Quartz window; (5) Inlet; (6) Outlet; (7) Light shutter.

\subsection{Photoelectrocatalytic degradation of the organics}

A set of organic solutions with diverse concentrations were injected into the reactor for exhaustive oxidation. After about $5 \mathrm{~min}$ the light intensity became stable. To prevent the influence of polarization current and the charging/discharging current of the capacitance load, the current-time measurement was initially performed in the dark for $20 \mathrm{~s}$ until the dark current became stable upon which the light shutter was opened and the TNA electrode was irradiated with UV light. The initial concentration of BPA was measured using a spectrophotometer (Shanghai Unico Co., UV 2102-PC, China) at a wavelength of $276 \mathrm{~nm}$. The current-time profiles were measured using an electrochemical workstation ( $\mathrm{CH}$ Instruments Inc, USA, and CHI660) that was coupled to a computer. A 4 W UV lamb (GE, G4T5, USA) was chosen as the irradiation source and the light intensity was measured with a UV-irradiance meter (Instruments of Beijing Normal University, FZ-A, China).

\section{Results and discussion}

\subsection{BPA photoelectrocatalysis in the thin-layer reactor}

Figure 2 shows a set of typical transient photocurrent-time profiles in the exhaustive oxidation mode at a fixed applied bias potential of $0.5 \mathrm{~V}$. The blank photocurrent ( $\left.I_{\text {blank }}\right)$ was obtained using the inert electrolyte solution originated from water oxidation while the total photocurrent $\left(I_{\text {total }}\right)$ obtained from the BPA solution was the total of two different components. One of these components originated from the photoelectrocatalytic oxidation of BPA and the other is from water oxidation, which is the same as $I_{\text {blank}}$. The net peak photocurrent $\left(I_{\text {net }}\right)$ was equal to the difference between $I_{\text {blank }}$ and $I_{\text {total }}$.

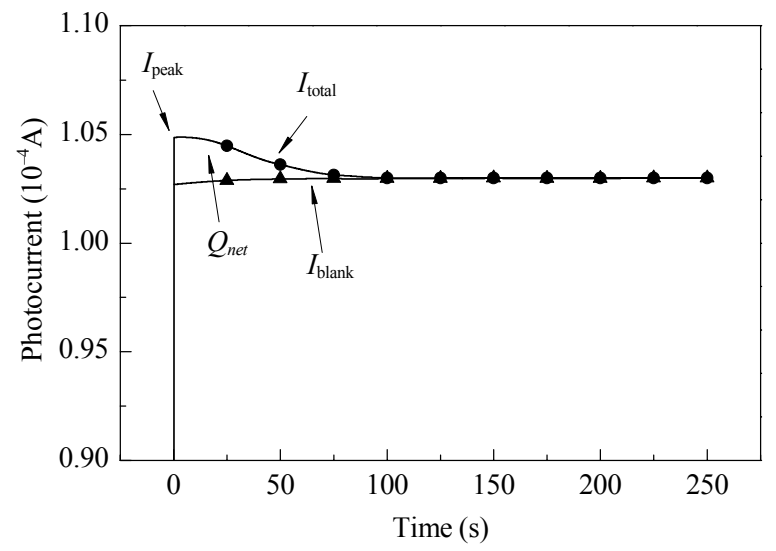

Fig. 2. Typical transient photocurrent-time profile in a $2.0 \mathrm{~mol} / \mathrm{L}$ $\mathrm{NaH}_{2} \mathrm{PO}_{4}$ blank solution, a $2.0 \mathrm{~mol} / \mathrm{L} \mathrm{NaH}_{2} \mathrm{PO}_{4}$ solution containing 35 $\mathrm{mg} / \mathrm{L}$ BPA under $0.66 \mathrm{~mW} / \mathrm{cm}^{2} \mathrm{UV}$ illumination in a thin-layer reactor based on a TNA photoanode.

When TNA is irradiated with photons that have an energy equal to or greater than the TNA bandgap energy the electrons can be excited from their valance band to the conductive band resulting in the generation of photohole/photoelectron pairs.

$$
\mathrm{TiO}_{2} \stackrel{E \geqslant E_{\mathrm{g}}}{\longrightarrow} \mathrm{h}^{+}+\mathrm{e}^{-}
$$

The photoelectrons from TNA transfer to the cathode if a sufficient bias potential is applied. This greatly simplifies the system and allows for a study of the photocatalytic oxidation process without the influence of the reduction half-reaction and the reduction reaction kinetics. In accordance with the single molecular layer Langmuir adsorption principle we assume that the degradation kinetics of organics by a $\mathrm{TiO}_{2}$ photoanode can be represented as:

$$
\mathrm{d} C / \mathrm{d} t=f\left(C_{\mathrm{s}}, C_{\mathrm{ad}}\right)=g\left(C_{\mathrm{s}}\right) \theta_{\mathrm{m}} k_{1} C_{\mathrm{b}} /\left(1+k_{1} C_{\mathrm{b}}\right)
$$

where $C_{\mathrm{s}}$ and $C_{\mathrm{ad}}$ represent the photohole concentration and the adsorbed organic concentration, respectively, $C_{\mathrm{b}}$ is the organic concentration in the bulk solution, $\theta_{\mathrm{m}}$ is the amount of single-molecule adsorption per unit surface area of the anode, and $k_{1}$ is the Langmuir adsorption constant.

When the concentration of organics is lower than the concentration of photoholes the photocurrent generated can be expressed as [26,27]: 


$$
I_{\text {net }}=n F A Z k_{2} C_{\mathrm{ad}}=n F A Z k_{2} \theta_{\mathrm{m}} k_{1} C_{\mathrm{b}} /\left(1+k_{1} C_{\mathrm{b}}\right)
$$

If the organic compound concentration is low enough, then $1+k_{1} C_{\mathrm{b}} \approx 1$ and Eq. (3) can be written as:

$$
\begin{gathered}
I_{\text {net }}=n F A Z k_{2} \theta_{\mathrm{m}} k_{1} C_{\mathrm{b}}=K C_{\mathrm{b}} \\
\mathrm{d} I_{\text {net }} / \mathrm{d} t=K \mathrm{~d} C_{\mathrm{b}} / \mathrm{d} t
\end{gathered}
$$

where $k_{2}$ and $K$ represent the organic degradation constant and the photocurrent response constant of the maximum adsorption, respectively, $F$ is the Faraday constant, $A$ is the surface area of the anode, $Z$ is the stoichiometric factor, $n$ is the total number of electrons transferred for the complete mineralization of the organics, and $I_{\text {net }}$ is the current that originates from the organic degradation.

If the assumption is valid the peak photocurrent response $\left(I_{\text {peak }}\right)$ can appear at the beginning of the photoelectrocatalytic reaction (Fig. 2). Experimentally, at less than $1 \mathrm{~s}$ after the TNA anode is irradiated, a rapid increasing in the current is apparent from light off to light on and the peak photocurrent decreases rapidly along with the depletion of BPA until it finally reaches an equivalency of $I_{\text {blank }}$.

\section{2 $I_{\text {net }}$ response with initial BPA concentration}

Figure 3 shows the relationship between the $I_{\text {net }}$ and the initial BPA concentration $\left(C_{\mathrm{b} 0}\right)$. It is evident that at a low concentration of BPA, $I_{\text {net }}$ is proportional to the initial BPA concentration and this is a result of the photohole capture process for mineralization. However, as the BPA concentration increases to the extent where the generation of photoholes is the limiting step the obtained $I_{\text {net }}$ becomes gradually saturated.

The relationship between the $I_{\text {net }}$ and $C_{\mathrm{b} 0}$ can be fitted as:

$$
\begin{aligned}
& I_{\text {net }}=2.2 \times 10^{-7} \times C_{\mathrm{b} 0} /\left(1+0.0945 C_{\mathrm{b} 0}\right)= \\
& 23.28 \times 10^{-7} \times 0.0945 C_{\mathrm{b} 0} /\left(1+0.0945 C_{\mathrm{b} 0}\right)
\end{aligned}
$$

The correlation coefficient $\mathrm{R}$, as determined by computer simulation is 0.9766 , indicating the validity of our assumption. The $I_{\text {net }}$ can directly reflect the rate of photohole consumption and BPA oxidation. $I_{\text {net }}$ vs. $C_{\mathrm{b} 0}$ is in agreement

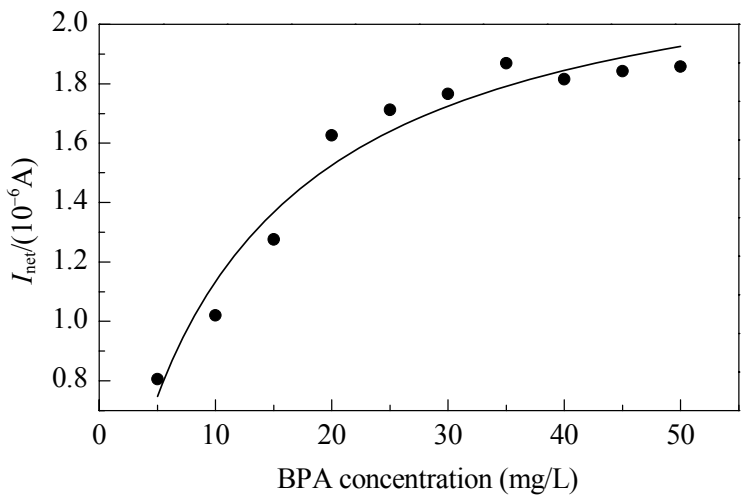

Fig. 3. The relationship between the $I_{\text {net }}$ and $C_{\mathrm{b} 0}$ in the $2.0 \mathrm{~mol} / \mathrm{L}$ $\mathrm{NaH}_{2} \mathrm{PO}_{4}$ electrolyte. with the single molecular layer Langmuir adsorption isotherm and a BPA adsorption constant of 0.0945 was obtained using Eqs. (2), (3), and (6). The linear relationship between the photocurrent and the organic concentration obtained from the Popović equation and the Henry adsorption model is limited to low concentration organic compounds. When the organic concentration is very high, $1+k_{1}$ $C_{\mathrm{b} 0} \approx k_{1} C_{\mathrm{b} 0}$, Eq. (3) can be written as:

$$
\begin{gathered}
I_{\text {net }}=n F A Z k_{2} \theta_{\mathrm{m}} k_{1} C_{\mathrm{b} 0} /\left(1+k_{1} C_{\mathrm{b} 0}\right) \approx \\
n F A Z k_{2} \theta_{\mathrm{m}} k_{1} C_{\mathrm{b} 0}=n F A Z k_{2}=K
\end{gathered}
$$

In this regard, the organic response photocurrent will saturate and become independent of the concentration when exceeding a certain value.

\subsection{Effect of $C_{\mathrm{b} 0}$ on the transient photocurrent-time response profile}

As discussed above, several hours or longer are usually required to assess the degradability of new toxic organics by a photocatalyst and the degradation kinetics data can be interfered with by intermediate products. The time dependent transient photocurrent response profile $\left(I_{\text {net }}-t\right)$ provides an effective solution to these problems. As shown in Fig. 4, every profile comprised 2500 data points that were recorded automatically by an electrochemical station. Similar to glucose oxidation in a thin-layer reactor the mass transfer of BPA is also very quick, which results in the exhaustive oxidation of BPA in the bulk solution within a short period of time. Only 1-3 min was required to completely mineralize BPA with various initial concentrations ranging from 5-45 $\mathrm{mg} / \mathrm{L}$.

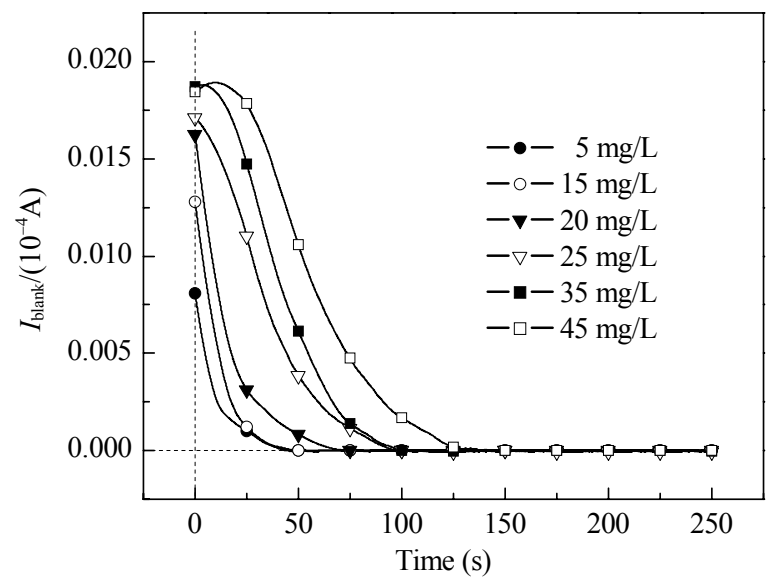

Fig. 4. Photocurrent response profiles derived from the photoelectrocatalytic oxidation of different concentrations of BPA in a thin-layer reactor.

A calculated fitting of the BPA transient net photocurrents is shown in Table 1 where $a, b$, and $m$ are the first-order 
Table 1 First-order exponential decay fitting of the BPA degradation time-dependent transient net photocurrent profiles using fitting function $I_{\text {net }}=a \mathrm{e}^{(-t / m)}+b$

\begin{tabular}{crrrc}
\hline BPA concentration $(\mathrm{mg} / \mathrm{L})$ & $a / 10^{-7}$ & \multicolumn{1}{c}{$m$} & \multicolumn{1}{c}{$b / 10^{-7}$} & $R^{*}$ \\
\hline 5 & 8.24 & 4.97 & 1.05 & 0.9629 \\
10 & 10.66 & 7.38 & -0.24 & 0.9887 \\
15 & 14.08 & 10.80 & 1.71 & 0.9908 \\
20 & 16.64 & 15.30 & 1.21 & 0.9935 \\
25 & 18.14 & 24.67 & 1.25 & 0.9864 \\
30 & 21.17 & 35.68 & 0.07 & 0.9877 \\
35 & 27.25 & 55.47 & -2.30 & 0.9826 \\
40 & 24.24 & 80.17 & -8.39 & 0.9747 \\
45 & 29.24 & 85.53 & -4.70 & 0.9809 \\
\hline
\end{tabular}

$R$ - Correlation coefficient.

exponential fitting parameters and $t$ represents the reaction time. We found that for all concentrations of BPA, $I_{\text {net }} t$ fits a first-order exponential decay model with correlation coefficients ranging from 0.9629 to 0.9935 , which is in good agreement with the concentration decay kinetics obtained using the traditional method [28]. These results confirm the validity of Eq. (5).

\subsection{Effect of irradiation intensity on the $I_{\text {net }}$ and $I_{\text {blank }}$}

We have discussed the effect of organics toward photoelectrocatalysis and fixing the photocatalysts under the same conditions. In fact, the relationship between the photocatalyst and the photoelectrocatalytic efficiency is more complicated. Many factors influence the production of photoholes and the oxidative reaction including the light emission spectra, the irradiation intensity, the surface area, the photoelectron transfer property and the photonic absorption spectrum of the photocatalyst, the light absorption properties of the electrolytes, and the reactor. Since all these factors are related to the $I_{\text {blank }}$ as will be discussed shortly we use the $I_{\text {blank }}$ to predict the photoelectrocatalytic efficiency and Eq. (2) can thus be written as:

$$
\begin{gathered}
\mathrm{d} C / \mathrm{d} t=\mathrm{d} I_{\text {net }} / \mathrm{d} t=f\left(C_{\mathrm{s}}, C_{\mathrm{ad}}\right)=g\left(C_{\mathrm{s}}\right) \theta_{\mathrm{m}} k_{1} C_{\mathrm{b} 0} \\
/\left(1+k_{1} C_{\mathrm{b} 0}\right)=K\left(\mathrm{~d} I_{\text {blank }} / \mathrm{d} t\right) \times \theta_{\mathrm{m}} k_{1} C_{\mathrm{b} 0} /\left(1+k_{1} C_{\mathrm{b} 0}\right)
\end{gathered}
$$

It is well-established that the photohole concentration is proportional to the intensity of light irradiation [18,29], therefore, we varied the distance between the UV lamp and the TNA anode to change the light intensity and hence the photohole concentration. The effect of light intensity upon $I_{\text {blank }}$ and the $I_{\text {net }}$ peak is given in Eqs. (9) and (10), based on the results shown in Fig. 5.

$$
\begin{array}{ll}
I_{\text {blank }}=1.54 x+0.0087 & R=0.9999 \\
I_{\text {net }}=1.83 x-0.0405 & R=0.9967
\end{array}
$$

The excellent linear fitting of the $I_{\text {blank }}$-light intensity and the $I_{\text {net }}$-light intensity indicates a proportional correlation between $I_{\text {blank }}$ and $I_{\text {net }}$ and the validity of Eq. (8).

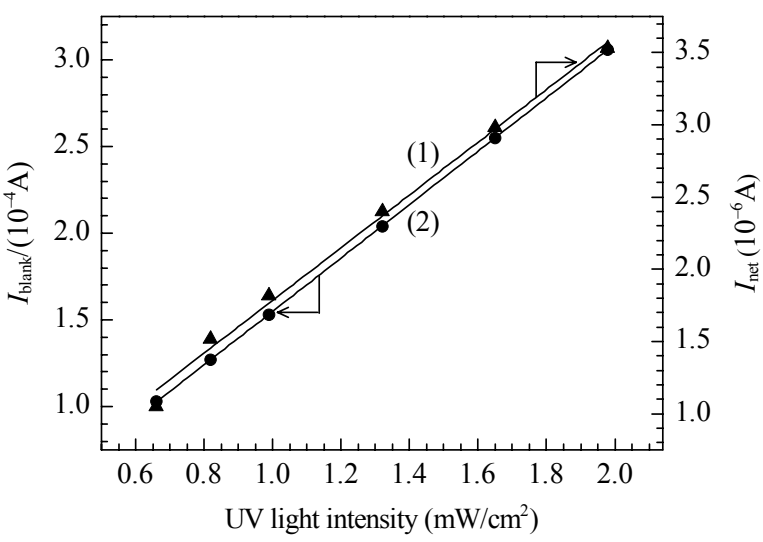

Fig. 5. Relationship between $I_{\text {net }}(1)$ and $I_{\text {blank }}(2)$ with the UV light intensity at a fixed BPA concentration of $35 \mathrm{mg} / \mathrm{L}$.

\subsection{Effect of irradiation intensity upon the exhaustive oxidation time $\left(t_{\mathrm{ex}}\right)$ and the exhaustive net charge quantity $\left(Q_{\text {net }}\right)$}

The effect of UV light intensity on the $t_{\mathrm{ex}}$ and the $Q_{\text {net }}$ are shown in Fig. 6 at a constant BPA concentration of $35 \mathrm{mg} / \mathrm{L}$. Here, $t_{\mathrm{ex}}$ decreases as the UV light intensity increases, indicating that the higher photohole concentration results in a quicker exhaustive degradation of BPA. However, the $Q_{\text {net }}$ of the BPA exhaustive oxidation was independent of the UV light intensity indicating that the photohole concentration has no effect on $Q_{\text {net. }}$. For the six different UV light intensities the average value of $Q_{\text {net }}$ was $(7.82 \pm 0.10) \times 10^{-4} \mathrm{C}$.

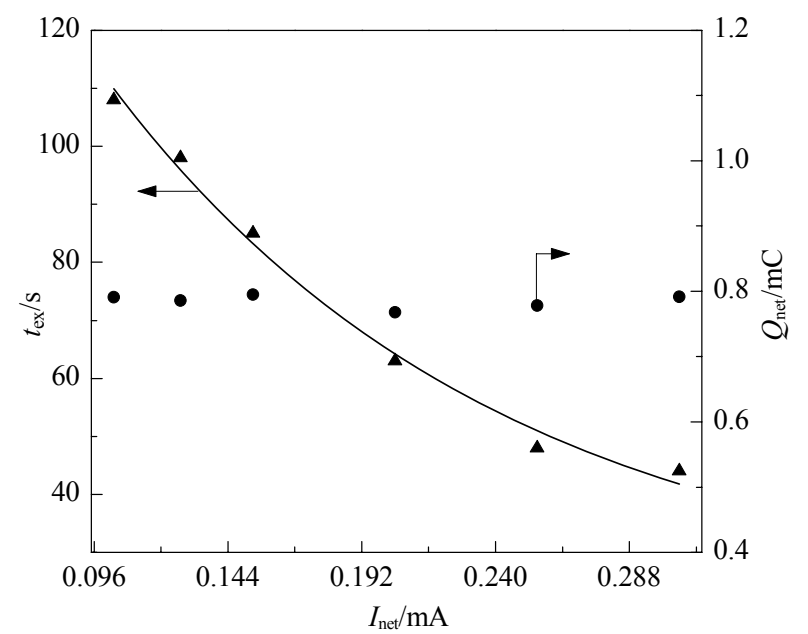

Fig. 6. The effect of irradiance on the exhaustive oxidation time $\left(t_{\mathrm{ex}}\right)$ and the exhaustive net charge quantity $\left(Q_{\text {net }}\right)$ at a fixed BPA concentration of $35 \mathrm{mg} / \mathrm{L}$ in the thin-layer reactor.

\section{6 $I_{\text {net }}$ response of various organics}

Figure 7 shows the relationship between the $I_{\text {net }}$ and the 

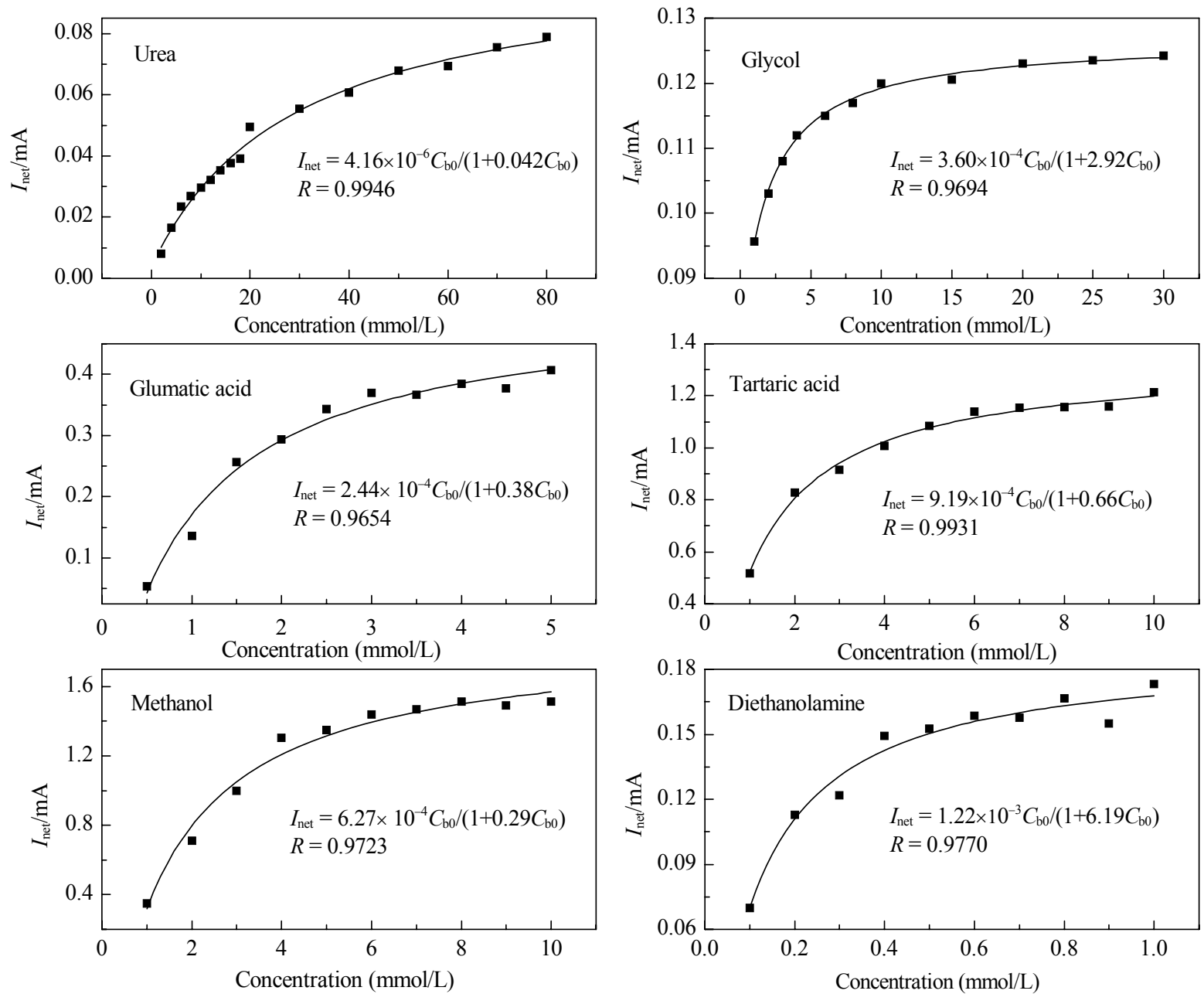

Fig. 7. The relationship between the organic concentration and the photocurrent response of the TNA anode for a series of organic compounds.

$C_{\mathrm{b} 0}$ for a series of organic compounds. All the relationships fit into a Langmuir adsorption isotherm model regardless the type of organics, and this is similar to the form of Eq. (6). All the photocurrent profiles obtained from a wide range of organic concentrations fit into first-order exponential decay models, which is similar to that of the BPA solutions. This also indicates that the photohole capture rate by low-concentration organics is a first order reaction with respect to the surface organic concentration, which in turn gives the instant rate of the overall photoelectrocatalytic oxidation. All the organic compounds used in this study were completely oxidized by the TNA electrode within 1-5 min with a consumption of only $5 \mathrm{ml}$ supporting electrolyte. As shown in Fig. 7, the adsorption constants of the different organics are 0.042 (urea), 2.92 (glycol), 0.38 (glumatic acid), 0.66 (tartaric acid), 0.29 (methanol), and 6.19 (diethanolamine), respectively. Different adsorption constants can lead to a disparity in the linear photoelectric sensing range and the organic oxidation rate but the same fitting model confirmed the validity of the determination of organic degradability by the TNA photoanode in a thin-cell reactor.

\section{Conclusions}

The characterization and mechanism of the photoelectrocatalytic degradation feasibility of organic pollutants was studied and validated in a thin-layer reactor. We used an anodic $\mathrm{TiO}_{2}$ nanotube array electrode as the photocatalyst and bisphenol-A as the target pollutant. Physical parameters such as the transient photocurrent, the initial net peak photocurrent, the exhaustive net charge quantity, and the blank photocurrent were investigated, which allowed us to inherently characterize the photoelectrocatalytic degradation of various organics. This study provides beneficial insights into how to assess the degradability of new toxic organic pollutants in a quick and safe way.

\section{References}

1 Kim D H, Anderson M A. Environ Sci Technol, 1994, 28: 479 
2 刘鸿, 冷文华, 吴合进, 成少安, 吴鸣, 张鉴清, 李文到, 曹 楚南. 催化学报 (Liu H, Leng W H, Wu H J, Cheng Sh A, Wu M, Zhang J Q, Li W Zh, Cao Ch N. Chin J Catal), 2000, 21: 209

3 Meng Q Q, Wang J G, Xie Q, Dong H Q, Li X N. Catal Today, 2011, 165: 145

4 Zhang A Y, Zhou M H, Liu L, Wang W, Jiao Y L, Zhou Q X. Electrochim Acta, 2010, 55: 5091

5 Zheng Q, Zhou B X, Bai J, Li L H, Jin Zh J, Zhang J L, Li J H, Liu Y B, Cai W M, Zhu X Y. Adv Mater, 2008, 20: 1044

6 Zheng Q, Zhou B X, Bai J, Cai W M, Liao J S. Prog Chem, 2007, 19: 117

7 Palmisano G, Loddo V, EI Nazer H H, Yurdakal S, Augugliaro V, Ciriminna R, Pagliaro M. Chem Eng J, 2009, 155: 339

8 Zhang W B, An T C, Xiao X M, Fu J M, Sheng G Y, Cui M H, Li G Y. Appl Catal A, 2003, 255: 221

9 Peill N J, Hoffmann M R. Environ Sci Technol, 1995, 29: 2974

10 Seung J Y, Im J H, Kim T, Lee K, Park C R. J Hazard Mater, 2011, 186: 376

11 An T C, Li G Y, Zhu X H, Fu J M, Sheng G Y, Kun Z. Appl Catal A, 2005, 279: 247

12 安太成, 张文兵, 朱锡海, 熊亚, 盛国英, 傅家谟. 催化学 报 (An T Ch, Zhang W B, Zhu X H, Xiong Y, Sheng G Y, Fu J M. Chin J Catal), 2003, 24: 338

13 王后锦, 吴晓婧, 王亚玲, 焦自斌, 颜声威, 黄浪欢. 催化 学报 (Wang H J, Wu X J, Wang Y L, Jiao Z B, Yan Sh W, Huang L H. Chin J Catal), 2011, 32: 637

14 Yu J G, Wang B. Appl Catal B, 2010, 94: 295
15 Hou Y, Li X Y, Zhao Q D, Quan X, Chen G H. Adv Funct Mater, 2010, 20: 2165

16 Dai G P, Yu J G, Liu G. J Phy Chem C, 2011, 115: 7339

17 Li X Z, Liu H L, Yue P T, Sun Y P. Environ Sci Technol, 2000, 34: 4401

18 刘冰川, 李金花, 周保学, 郑青, 白晶, 张嘉凌, 刘艳彪, 蔡 伟民. 催化学报 (Liu B Ch, Li J H, Zhou B X, Zheng Q, Bai J, Zhang J L, Liu Y B, Cai W M. Chin J Catal), 2010, 31: 163

19 Liu Y B, Zhou B X, Bai J, Li J H, Zhang J L, Zheng Q, Zhu X Y, Cai W M. Appl Catal B, 2009, 89: 142

20 Liu Y B, Zhou H B, Zhou B X, Li J H, Chen H C, Wang J J, Bai J, Shangguan W F, Cai W M. Int J Hydrogen Energy, 2011, 36: 167

21 Bai J, Li J H, Liu Y B, Zhou B X, Cai W M. Appl Catal B, 2010, 95: 408

22 Bai J, Liu Y B, Li J H, Zhou B X, Zheng Q, Cai W M. Appl Catal B, 2010, 98: 154

23 Zhang J L, Zhou B X, Zheng Q, Bai J, Li J H, Liu Y B, Cai W M. Water Res, 2009, 43: 1986

24 Zheng Q, Han H B, Zhou B X, Li J H, Bai J, Cai W M. Chin Sci Bull, 2009, 54: 3241

25 Li J H, Zhou B X, Shao J H, Yang Q F, Liu Y B, Cai W M. Chemosphere, 2007, 68: 1298

26 Popović N D, Johnson D C. Anal Chem, 1998, 70: 468

27 Beranek R, Kisch H. Electrochem Commun, 2007, 9: 761

28 Tian M, Wu G S, Adams B, Wen J L, Chen A C. J Phys Chem $C, 2008,112: 825$

29 Jiang D, Zhao H, Zhang S, John R. J Phys Chem B, 2003, 107: 12774 